\title{
The Effectiveness of Interaction Between Chemical Fungicides, Bio-Agent and Plant Densities on the White Mold Disease in the Common Bean
}

\author{
Itamar Rosa Teixeira ${ }^{1}$, Lucas Roberto de Carvalho ${ }^{1}$, Elton Fialho dos Reis ${ }^{1}$, Alessandro Guerra da Silva ${ }^{2} \&$ \\ Gisele Carneiro da Silva Teixeira ${ }^{3}$ \\ ${ }^{1}$ Universidade Estadual de Goiás, Unidade de Anápolis, Programa de Pós-Graduação em Engenharia Agrícola, \\ Anápolis, Goiás, Brazil \\ ${ }^{2}$ Universidade Rio Verde, Programa de Pós-Graduação em Produção Vegetal, Rio Verde, Goiás, Brazil \\ ${ }^{3}$ Universidade Federal de Goiás, Programa de Pós-Graduação em Solo e Água, Goiânia, Goiás, Brazil \\ Correspondence: Itamar Rosa Teixeira, Universidade Estadual de Goiás, Unidade de Anápolis, Programa de \\ Pós-Graduação em Engenharia Agrícola, Anápolis, Goiás, Brazil. Tel: 55-62-3328-1156. E-mail: \\ itamarrt@yahooo.com.br
}

Received: April 16, 2013 Accepted: May 18, 2013 Online Published: June 15, 2013

doi:10.5539/jas.v5n7p255 URL: http://dx.doi.org/10.5539/jas.v5n7p255

\begin{abstract}
White mold (Sclerotinia sclerotiorum) is a major problem of the common bean in Brazil. Thus, the objective of this study was to verify the effectiveness of chemical fungicides and biological products (Trichoderma spp) for the control of white mold in a bean field with different plant population densities located in the Silvânia, Goiás State, Brazil, in the 2007/08 rain season. The experimental design was the randomized blocks, with four replicates and seven treatments. The treatments are consisting of two levels of plant population densities (240 and 120 thousand plants $/ \mathrm{ha}^{-1}$ ), chemical fungicides (carboxin-thiram and procymidone) and biological fungicides (Trichoderma spp), as well as untreated control. The results indicated that there was no significant interaction between bean population densities and chemical and biological fungicides applied to control S. sclerotiorum. The biological agent Trichoderma spp. is not effective in controlling S. sclerotiorum in common bean crop grown in the Brazilian "cerrado" region. Application of carboxin-thiram + procymidone was the most efficient treatment for the control of white mold on the common bean. Lower planting density is recommended for areas contaminated with $S$. sclerotiorum, as it can be easily associated with other control strategies.
\end{abstract}

Keywords: Phaseolus vulgaris, Sclerotinia sclerotiorum, chemical fungicides, Trichoderma spp.

\section{Introduction}

The common bean (P. vulgaris L.) constitutes the basic daily protein source in the diet of the Brazilian population. In Brazil, the legume is grown throughout the year in a wide variety of agro-systems, and a number of both biotic and abiotic factors limit its production. Among biotic factors, the occurrence of diseases such as white mold $(S$. sclerotiorum) in which considered a serious problem to the crop today, especially in irrigated areas of cerrado (Peres et al., 2002; Napoleão et al., 2007; Gomes et al., 2011).

Generally the incidence of white mold increases in situations of mild temperature (Kimati, 1995). The period of leaf wetness from 48 to 72 hours is sufficient for occurrence of infection by ascospores. However, in flowers only 16 to 24 hours are necessary for infection (Abawi \& Grogan, 1979). The degree of injury of the disease is dependent on the initial inoculum density, wetness duration, cultural practices and population densities. Additionally, Stone and Moreira (2001), Paula Júnior et al. (2009), Macena et al. (2011) add the compression factor and dense populations as factors responsible for worsening of the problem.

Among the promising alternatives bio-agent to control the white mold is using the antagonistic microorganisms in the soil, such as Trichoderma spp. (Ethur et al., 2005; Mansour et al., 2008; Baniasadi et al., 2009). However, in field conditions the control of S. sclerotiorum by microorganisms has rarely been reported (Huang et al., 2000; Görgen et al., 2009; Paula Júnior et al., 2012). 
Despite the effectiveness of chemical fungicides but have problems related to resistance and environmental contamination (Gossen et al., 2001; Li et al., 2003), and therefore alternatives must be sought in order to provide conditions that favor the biological control agents of the pathogen in the field. Hence, the objective of this study was to evaluate the efficacy of certain chemical and biological agents in addition plant population densities against the white mold.

\section{Materials and Methods}

\subsection{Description of the Study Area}

The experiment was conducted in the 2007/08 rain season, in a no-tillage system, at Silvânia - GO, Brazil, 16³9'S and $48^{\circ} 37^{\prime} \mathrm{O}$, altitude of 898 . The regional climate is classified as humid tropical, with precipitation and average annual temperature of $1450 \mathrm{~mm}$ and $23^{\circ} \mathrm{C}$, respectively. In this area soybeans (spring-summer) have been alternated with beans (autumn-winter and winter) for more than five years, and inoculum density analysis indicated the presence of 22 sclerotia $\mathrm{m}^{2}$.

Physical and chemical analysis of soil samples classified as dystrophic Red-Yellow Latosol found in Table 1.

Table 1. Soil physical and chemical properties before the experiment $(0-20 \mathrm{~cm}$ depth)

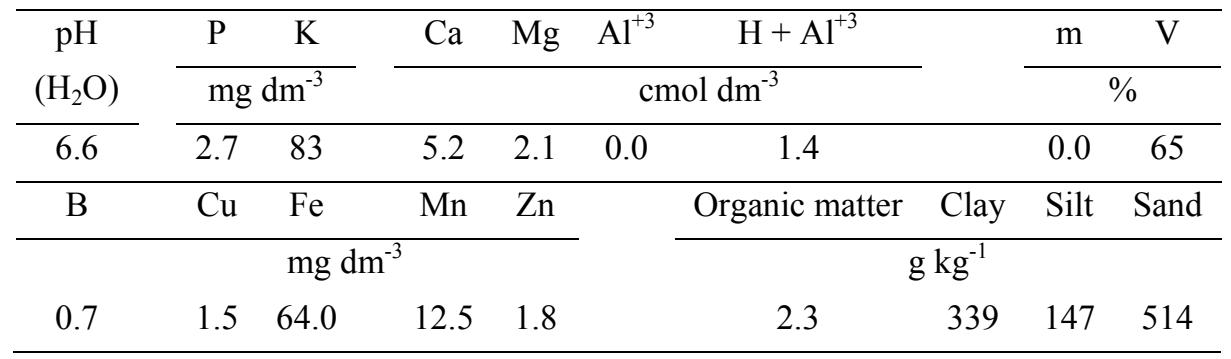

\subsection{Experimental Design and Conduct of the Study}

The experimental design was a $5 \times 2$ factorial in randomized blocks, with four replicates. Treatments consisted of two levels of plant population densities (240 and 120 thousand plants ha $\left.{ }^{-1}\right)$ and five control treatments (untreated control, seed inoculation by Trichoderma + Trichoderma at post-emergence, seed inoculation by carboxin-thiram + Trichoderma at post-emergence, seed inoculation by carboxin-thiram + procymidone at post-emergence, seed inoculation by Trichoderma + procymidone at post-emergence). The products of Trichoderma and carboxin-thiram were applied to the seeds in rates of $200 \mathrm{~g}$ and $100+100 \mathrm{ml}$ to $100 \mathrm{~kg}$ of commercial seeds, respectively. At post-emergence the applied dose of Trichoderma was $1.2 \mathrm{ml} \mathrm{ha}^{-1}$ and $0.5 \mathrm{~kg} \mathrm{ha}^{-1}$ for procymidone (Biovale ${ }^{\circledR}$ ) a commercial formulation of $T$. viride and $T$. harzianum was used as a biological control agent, with constant flow rate of $300 \mathrm{~L} \mathrm{ha}^{-1}$ and addition of mineral oil at $0.5 \%$ of spray measure. Foliar applications were performed at the beginning of the flowering stage and repeated two more times with an interval of 15 days, using a $\mathrm{CO}_{2}$ backpack sprayer at a pressure of $30 \mathrm{psi}$ and flow of $1.5 \mathrm{~L} / \mathrm{min}$. During the applications, plastic drop cloths $(6.0 \times 1.8 \mathrm{~m})$ were placed on all sides of the plot to control spraying.

Plots consisted of four rows measuring $5.0 \mathrm{~m}$ long, spaced at $0.50 \mathrm{~m}$, using the two central lines as a floor area, eliminating $0.50 \mathrm{~m}$ on each side as a border. Cultivar Pérola was used which has a semi-erect to prostrate growth habit (type II/III), carioca grain type and is widely used by producers in the region of the study. Fertilization was applied with $450 \mathrm{~kg} \mathrm{ha}^{-1}$ of the formulation $05-25-20\left(\mathrm{~N}_{-} \mathrm{P}_{2} \mathrm{O}_{5}\right.$ and $\left.\mathrm{K}_{2} \mathrm{O}\right)$ at planting, followed by cover fertilization with $40 \mathrm{~kg} \mathrm{ha}^{-1}$ of urea at 25 days after emergence (DAE).

Foliar sprayings were carried out with a mixture of fungicides mancozeb $\left(2.0 \mathrm{~kg} \mathrm{ha}^{-1}\right)$ and azoxystrobin $\left(0.1 \mathrm{~kg} \mathrm{ha}^{-1}\right)$ for controlling anthracnose (Colletrotrichum lindemuthianum), rust (Uromyces appendiculatus) and angular leaf spot (Phaeoisariopsis griseola), taking care to not interfere with the test treatments. Other cultural practices were those normally applied to the crop.

\subsection{Evaluation of the Study}

During the full flowering stage phase the number of apothecia on the surface of the soil in each plot was counted, as well as the incidence of the disease in plants considering the percentage of plants with symptoms of the disease. Disease severity was also quantified, according to the scale proposed by Napoleão et al. (2005): 1 - apparently healthy plant, $2-1 \%$ to $5 \%$ of the plant attacked, $3-6 \%$ to $20 \%$ of plant attacked; $4-21 \%$ to $50 \%$ of plant attacked; 
5 - more than 50\% plant attacked, and 6 - dead plant. With the values obtained for evaluation of severity, the disease index (ID) was calculated according to the formula established by Mckinney (1923).

$$
\text { ID }(\%)=\frac{\Sigma(\text { grade of severity } x \text { number of plants with this grade })}{(\text { total number of plants } x \text { maximum value of the severity scale })} \times 100
$$

At the time of harvest the aerial portion of each plot was collected from all plants for estimation of the grain yield. In the referred area 10 plants were taken for quantification of the yield components (number of pods per plant, number of seeds per pod and weight of 100 grains). Also, the final stand of the plants and the quantity of sclerotia larger than two millimeters on the grains of each plot were evaluated.

\subsection{Statistical Analysis}

The data was subjected to analysis of variance, and when differences among treatments were significant, means were compared by the Tukey test at $5 \%$ probability.

\section{Results and Discussion}

\subsection{Evaluations of the White Mold}

There were significant effects between the different alternatives for the control of white mold on beans regarding the assessments on the number of apothecia, incidence, severity index and number of sclerotia. For the plant population densities all evaluations showed significant response to application of the treatments except for severity (ID). No significant interaction was detected for control treatments with plant population densities.

The application of carboxin-thiram via the seed + procymidone at post-emergence, followed by carboxin-thiram via seed + Trichoderma at post-emergence and Trichoderma via the seed and procymidone generally resulted in marked decrease of the damage promoted by white mold on bean area, as can be noticed by the existing percentages for the number of apothecia, incidence, disease severity index and number of sclerotia in the respective treatments (Table 1). In contrast, the greatest manifestations of the disease were observed in the control, followed by the treatment with Trichoderma added via the seed and at post-emergence (Table 2). According to Costa and Costa (2004), the use of fungicides to control white mold is effective only in areas where the density of inoculum is up to $27 \mathrm{sclerotia} / \mathrm{m}^{2}$.

Table 2. Average values for the number of apothecia (NA), disease incidence (INC), severity disease index (ID) and number of sclerotia (NS) in bean common plants under different plant population densities, and alternatives for control of white mold

\begin{tabular}{lllll}
\hline Treatment & \multicolumn{3}{c}{ Variables } \\
\cline { 2 - 5 } & NA & INC (\%) & ID & NS \\
\hline \multicolumn{2}{l}{ Chemical or biological treatment } & & & $302,0 \mathrm{a}$ \\
\hline $\mathrm{C}^{1}$ & $30,0 \mathrm{a}^{6}$ & $83,9 \mathrm{a}$ & $41,4 \mathrm{a}$ & $251,8 \mathrm{a}$ \\
$\mathrm{TT}^{2}$ & $27,6 \mathrm{a}$ & $34,5 \mathrm{~b}$ & $39,4 \mathrm{a}$ & $42,8 \mathrm{c}$ \\
$\mathrm{CTT}^{3}$ & $10,6 \mathrm{bc}$ & $20,8 \mathrm{bc}$ & $4,4 \mathrm{~b}$ & $28,8 \mathrm{c}$ \\
$\mathrm{CTP}^{4}$ & $5,0 \mathrm{c}$ & $13,4 \mathrm{c}$ & $4,1 \mathrm{bc}$ & $95,8 \mathrm{~b}$ \\
$\mathrm{TP}^{5}$ & $12,3 \mathrm{~b}$ & $24,3 \mathrm{bc}$ & $6,2 \mathrm{~b}$ & \\
\hline
\end{tabular}

Plant population densities (1000 plants ha ${ }^{-1}$ )

\begin{tabular}{lllll}
\hline 120 & $12,8 \mathrm{~b}^{7}$ & $31,9 \mathrm{~b}$ & $18,0 \mathrm{a}$ & $136,8 \mathrm{~b}$ \\
240 & $21,4 \mathrm{a}$ & $38,8 \mathrm{a}$ & $20,2 \mathrm{a}$ & $151,5 \mathrm{a}$ \\
\hline Means & 17,1 & 35,4 & 19,1 & 144,2 \\
\hline C.V. & 23,37 & 21,22 & 28,13 & 23,65
\end{tabular}

${ }^{1} \mathrm{C}=$ untreated control; ${ }^{2} \mathrm{TT}=$ Trichoderma via the seed + Trichoderma at post-emergence $;{ }^{3} \mathrm{CTT}=$ Carboxin + Thiram via the seed + Trichoderma at post-emergence; ${ }^{4} \mathrm{CTP}=$ Carboxin + Thiram via the seed + Procymidone at post-emergence and ${ }^{5} \mathrm{TP}=$ Trichoderma via the seed + Procymidone at post-emergence.

${ }^{6}$ Means followed by different letters in the columns differed at $5 \%$ probability by the Tukey test. ${ }^{7}$ Measurements followed by different letters in the columns differ at $5 \%$ probability by the $\mathrm{F}$ test. 
Table 2 shows that plant density is a risk factor for the "aggravation" of the disease in the field (Table 1). In lower planting densities there is greater air circulation between plants, which contributes to the lower intensity of white mold (Charchar et al., 1991; Park, 1993; Saidon et al., 1993; Napoleão et al., 2005). Tu (1997) recorded that the greater plant population densities and smaller spacing contributed to an increased intensity of white mold, increasing premature senescence and contact between plants, which increasing of the disease incidence in the field. Therefore, the obtained results in this study agree with those found in literature where the intensity of white mold increases in dense plantings compared with more widely spaced plantings (Charchar et al., 1991; Park, 1993; Saidon et al., 1993; Paula Júnior et al., 2009; Macena et al., 2011).

\subsection{Agronomic Characteristics}

Grain yield of the common bean and its components (number of pods per plant, number of grains per pod and weight of one hundred beans), as well as the final stand and the number of sclerotia in the seed mass were significantly affected by the single effects of control treatments and the plant population densities, with no interaction effect (planting density $\mathrm{x}$ chemical and/or biological fungicide).

The presence of $S$. sclerotiorum proved reduction in the population of bean plants in the area, as can be verified in the plot without fungicide application (control) and in the treatment with Trichoderma via the seed and at post-emergence (Table 3). These results agree with those obtained for evaluating the number of apothecia, disease incidence, disease severity index and number of sclerotia (Table 2). The average final stand corresponded to 10.8 plants $\mathrm{m}^{-1}$, which can be considered normal for the bean based on the densities of used plant population (Table 3).

Among the yield components, the number of pods per plant was most strictly related to grain yield (Table 3 ). This parameter is expected in two other components, number of beans per pod and weight of one hundred beans, which are genetic characteristics, and therefore are little influenced by the environment; however there was a differentiated effect between treatments that employed a combination of chemical fungicides and biological agents compared with the untreated control.

The fungicides carboxin-thiram plus procymidone at post-emergence stood out with regard to disease control compared with the application of the antagonistic fungi Trichoderma and the treatment without fungicide or application of the antagonist. The fungicide was effective in reducing not only the incidence and severity of white mold, but also the number of sclerotia of the fungus adhered to the pods and mixed with the seeds.

The treatment in which the fungicide carboxin-thiram plus procymidone was employed, followed by carboxin-thiram + Trichoderma and Trichoderma + procymidone generally excelled at controlling the disease when compared with application of the antagonistic fungi Trichodema alone and treatment without the application of the fungicide or the antagonist. In addition to, the effects on disease control, the application of carboxin-thiram via seeds and procymidone at post-emergence indicated productivity gains of circa $59 \%$ and $42 \%$, compared with the control treatment and that in which only Trichoderma was employed, respectively (Table 3).

Fungicides such as carboxin-thiram and procymidone perform protective action, with systemic and contact activity (Kimati, 1995). Vieira et al. (2001) demonstrated efficiency of fungicides such as procymidone in control of white mold on bean under field conditions in the "Zona da Mata", MG, Brazil.

The lower density planting $\left(120\right.$ plants $\left.^{-1} \mathrm{a}^{-1}\right)$, did not cause a decrease in the yield of beans as could be expected in areas free of white mold; rather, several yield components were higher in at a population density of 120 plants ha $^{-1}$ (Table 3). Similar results with the use of less dense spacing and fewer plants per rows were encountered by Vieira et al. (2001) and Paula Júnior et al. (2009). Teixeira et al. (2000) also reported that the production of grains may be greater in less densely planted areas.

The common bean plant is known for its great compensation ability, i.e., when planted in smaller densities it suffers less intraspecific competition and may have a greater number of buds on the main stem and branches, producing a greater number of pods per plant. In larger population densities the increase in the number of plants triggers a reduction in the number of pods produced; this compensation had been found by other authors (Valério et al., 1999; Teixeira et al., 2004). Moreover, the compensation capacity coupled with greater aeration and unfavorable effects on the development of white mold makes use of lower seeding rates a viable strategy for areas infested with $S$. sclerotiorum. 
Table 3. The average values of the final stand (SF), pod number per plant (NPP), grain number per pod (NGP), 100 seed weight (100SW) and grain yield (GY) in bean common plants under different plant population densities and alternatives to control the white mold

\begin{tabular}{llllll}
\hline \multirow{2}{*}{ Treatment } & \multicolumn{5}{c}{ Variables } \\
\cline { 2 - 6 } & $\begin{array}{l}\text { SF } \\
\left(5 \mathrm{~m}^{2}\right)\end{array}$ & NPP & NGP & $\begin{array}{l}100 \mathrm{SW} \\
(\mathrm{g})\end{array}$ & $\begin{array}{l}\mathrm{GY} \\
\left(\mathrm{kg} \mathrm{ha}^{-1}\right)\end{array}$ \\
\hline \multicolumn{2}{l}{ Chemical or biological treatment } & & & $21,1 \mathrm{~b}$ & $1011,2 \mathrm{c}$ \\
\hline $\mathrm{C}^{1}$ & $96 \mathrm{~b}^{6}$ & $9,6 \mathrm{~b}$ & $3,6 \mathrm{~b}$ & $22,5 \mathrm{ab}$ & $1117,9 \mathrm{c}$ \\
$\mathrm{TT}^{2}$ & $113 \mathrm{ab}$ & $10,1 \mathrm{ab}$ & $3,9 \mathrm{a}$ & $23,0 \mathrm{a}$ & $1536,3 \mathrm{~b}$ \\
$\mathrm{CTT}^{3}$ & $118 \mathrm{a}$ & $14,5 \mathrm{a}$ & $3,8 \mathrm{a}$ & $22,9 \mathrm{a}$ & $1608,2 \mathrm{a}$ \\
$\mathrm{CTP}^{4}$ & $120 \mathrm{a}$ & $13,2 \mathrm{a}$ & $3,9 \mathrm{a}$ & $21,5 \mathrm{ab}$ & $1421,0 \mathrm{~b}$ \\
$\mathrm{TP}^{5}$ & $116 \mathrm{a}$ & $12,9 \mathrm{a}$ & $3,9 \mathrm{a}$ & &
\end{tabular}

Plant population densities (1000 plants ha $\left.{ }^{-1}\right)$

\begin{tabular}{llllll}
\hline 120 & $75 \mathrm{~b}$ & $14,1 \mathrm{a}$ & $4,1 \mathrm{a}$ & $23,8 \mathrm{a}$ & $1695,4 \mathrm{a}$ \\
240 & $118 \mathrm{a}$ & $10,0 \mathrm{~b}$ & $3,5 \mathrm{~b}$ & $20,4 \mathrm{~b}$ & $982,4 \mathrm{~b}$ \\
\hline Means & 108 & 12,1 & 3,8 & 22,17 & 1338,9 \\
\hline C.V. & 18,34 & 19,69 & 10,16 & 13,10 & 20,42 \\
\hline
\end{tabular}

${ }^{1} \mathrm{C}=$ untreated control; $\mathrm{TT}={ }^{2}$ Trichoderma via the seed + Trichoderma at post-emergence; ${ }^{3} \mathrm{CTT}=$ Carboxin + Thiram via the seed + Trichoderma at post-emergence; ${ }^{4} \mathrm{CTP}=$ Carboxin + Thiram via the seed + Procymidone at post-emergence and ${ }^{5} \mathrm{TP}=$ Trichoderma via the seed+ Procymidone at post-emergence.

${ }^{6}$ Means followed by different letters in the columns differed at $5 \%$ probability by the Tukey test. ${ }^{7}$ Measurements followed by different letters in the columns differ at $5 \%$ probability by the $\mathrm{F}$ test.

Application of Trichoderma alone wasn't effective against white mold, agreeing with the results of Paula Júnior et al. (2009), although other studies have demonstrated the potential of its use (Pereira et al., 1996; Görgen et al., 2009). It is suggested that one of the main reasons for inefficiency of the antagonist in the field are related to low supply of organic material in the no-tillage system (decomposing soybean straw), since it is in organic matter that the antagonist develops and becomes more competitive with other microorganisms. Also, the concentration of spores per $\mathrm{ml}$ in product may play an important of effectivness.

It can thus be inferred that establishment of the antagonist in soil is hampered by the lack of organic matter, where it must also be taken into consideration that the lack of vegetation and organic residues caused greater exposure of soil and initial Trichordema inoculum to solar rays, making conditions inappropriate for its survival (Boland, 1997; Görgen et al., 2009). Similarly, application at post-emergence, in the phase of intense flowering of the plants, was similarly affected by high temperatures favoring S. sclerotiorum over Trichodema, which was more slowly established and thus no antagonistic effect was observed. It should be considered, as reported by Cardoso et al. (1997), that the failure of most disease control antagonist likely results from the high potential of the pathogen inoculum, although inconsistent data is common. Paula Junior et al. (2012) add that to occur at low temperatures of common bean crop cultivated at the fall-winter season can also decrease the effectiveness of the biological agent Trichoderma spp. on the pathogen S. sclerotiorum.

New studies using Trichoderma for control of white-mold on beans are suggested, especially studies associated with other commonly used fungicides in the bean crop.

\section{Conclusions}

There is no significant interaction between population densities of bean plants and chemical and biological fungicides applied to control S. sclerotiorum. Moreover, the biological agent Trichoderma spp. is not effective to control S. sclerotiorum in common bean crop grown in the Brazil. Also, application of carboxin-thiram + procymidone recorded the highest control of white mold disease in the common bean. Lower planting densities are recommended for areas contaminated with S. sclerotiorum. 


\section{References}

Abawi, G. S., \& Grogan, R. G. (1979). Epidemiology of disease caused by Sclerotinia species. Phytopathology, 69, 899-904. http://dx.doi.org/10.1094/Phyto-69-899

Baniasadi, F., Bonjar, G. H. S., Baghizadeh, A., Nick, A. K., Jorjandi, M., Aghighi, S., \& Farokhi, P. R. (2009). Biological control of Sclerotinia sclerotiorum, causal agent of sunflower head and stem rot disease, by use of soil borne actinomycetes isolates. American Journal of Agricultural and Biological Science, 4(2), 146-151. http://dx.doi.org/10.3844/ajabssp.2009.146.151

Boland, G. J. (1997). Stability analysis for evaluating the influence of environment on chemical and biological control of white mold (Sclerotinia sclerotiorum) of bean. Biological Control, 9(1), 7-14. http://dx.doi.org/10.1006/bcon.1997.0515

Cardoso, J. E., Silva, S. A. G., \& Marques, E. E. (1997). Controle qunímico e biológico de podridões radiculares do feijoeiro comum. Fitopatologia Brasileira, 22(1), 39-44.

Charchar, M. J. D. A.,Nasser, L. C. B., Barreto, L. A. J. C., \& Vivaldi, L. J. (1991). Efeito de diferentes práticas culturais no controle de mofo-branco (Sclerotinia sclerotiorum) no feijoeiro irrigado. Fitopatologia Brasileira, 16(2), 20.

Costa, G. R., \& Costa, J. L. S. (2004). Efeito da aplicação de fungicidas no solo sobre a germinação carpogênica e miceliogênica de escleródios de Sclerotinia sclerotiorum.Pesquisa Agropecuária Tropical, 34(3), $133-138$.

Ethur, L. Z., Blume, E., Muniz, M., Silva, A. C. F., Stefanelo, D. R., \& Rocha, E. K. (2005). Fungos antagonistas a Sclerotinia sclerotiorumem pepineiro cultivado em estufa. Fitopatologia Brasileira, 30(2), 127-133. http://dx.doi.org/10.1590/S0100-41582005000200004

Gomes, E. V., Nascimento, L. B., Freitas, M. A., Nasser, L. C. B., \& Petrofeza, S. (2011). Microsatellite markers reveal genetic variation within Sclerotinia sclerotiorum populations in irrigated dry bean crops in Brazil. Journal of Phytopathology, 159(2), 94-99. http://dx.doi.org/10.1111/j.1439-0434.2010.01724.x

Görgen, C. A.,Silveira Neto, A. N., Carneiro, L. C., Ragagnin, V., \& Lobo Júnior, M. (2009). Controle do mofo-branco com palhada e Trichoderma harzianum 1306 em soja. Pesquisa Agropecuária Brasileira, Brasilia, 44(12), 1583-1590. http://dx.doi.org/10.1590/S0100-204X2009001200004

Gossen, B. D., Rimmer, S. R., \& Holley, J. D. (2001). First report of resistence benomyl fungicide in Sclerotinia sclerotiorum. Plant Disease, 85(8), 1206-1222. http://dx.doi.org/10.1094/PDIS.2001.85.11.1206C

Huang, H. C., Bremer, E., Hynes, R. K., \& Erickson, R. S. (2000). Foliar application of fungal biocontrol agents for the control of white mold of dry bean caused by Sclerotinia sclerotiorum.Biological Control, 18(2), 270-276. http://dx.doi.org/10.1006/bcon.2000.0829

Kimati, H. (1995). Controle químico. In A. Bergamin Filho, H. Kimati, \& L. Amorim (Eds.), Manual de fitopatologia: princípios e conceitos (3th ed.). São Paulo. Editora Agronômica Ceres, 1, 761-785.

Li, G. K., Hung, H. C., \& Acharya, S. N. (2003). Antagonism and biocontrol potential of Ulocladium atrumon Sclerotinia sclerotiorum. Biological Control, 28(1), 1-18. http://dx.doi.org/10.1016/S1049-9644(03)00050-1

Macena, A. M. F., Canteri, M. G., \& Ferreira Júnior, J. P. (2011). Espaçamento e manejo de restos culturais para o controle de Sclerotinia sclerotiorum em feijoeiro. Ciência Rural, 41(11), 1871-1873. http://dx.doi.org/10.1590/S0103-84782011001100003

Mansour, T., Abdullah, N. Y. A., \& Sulleman, P. (2008). Biological controlo of Sclerotinia sclerotiorum (Lib.) de Bary with Trichoderma harzianum and Bacillus amyloliquefaciens. Crop Protection, 27(10), 1354-1359. http://dx.doi.org/10.1016/j.cropro.2008.05.007

Mckinney, R. H. (1923). Influence of soil temperature and moisture on infection of wheat seedlings by Helminthosporium sativum. Journal of Agricultural Research, 6(3), 195-218.

Napoleão, R., Café-Filho, A. C., Lopes, C. A., Nasser, L. C. B., \& Marouelli, W. A. (2007). Efeito da freqüência de rega e da umidade do solo sobre a germinação carpogênica de Sclerotinia sclerotiorum. Summa Phytopathologica, 33(1), 80-82. http://dx.doi.org/10.1590/S0100-54052007000100012

Napoleão, R., Café-Filho, A. C., Nasser, L. C. B., Lopes, C. A., \& Silva, H. R. (2005). Intensidade do mofo branco do feijoeiro em plantio convencional e direto sob diferentes lâminas d'água. Fitopatologia Brasileira, 30(4), 374-379. http://dx.doi.org/10.1590/S0100-41582005000400006 
Park, S. J. (1993). Response of bush and upright plant type selections to white mold and seed yeld of commom beans grown in various row wids in sorthem Ontario. Canadian Journal of Plant Science, 73(2), 265-272. http://dx.doi.org/10.4141/cjps93-041

Paula Júnior, T. J., Teixeira, H., Vieira, R. F., Morandi, M. A. B., Lehner, M. S., Lima, R. C., \& Carneiro, J. E. S. (2012). Limitações no controle do mofo branco no feijão em Trichoderma spp. na temporada de $\begin{array}{llll}\text { outono-inverno. Summa 337-340. } & \text { Phytopathologica, }\end{array}$ http://dx.doi.org/10.1590/S0100-54052012000400012

Paula Júnior, T. J., Vieira, R. F., Rocha, P. R. R., Bernardes, A., Costa, E. L., Carneiro, J. E. S., ... Zambolim, L. (2009). White mold intensity on common bean in response to plant density, irrigation frequency, grass mulching, Trichoderma spp., and fungicide. Summa Phytopathologica, 35(1), 44-48. http://dx.doi.org/10.1590/S0100-54052009000100007

Pereira, J. C. R., Chaves, G. M., Zambolim, L., Matsuoka, K., Silva-Acuna, R., \& Vale, R. X. R. (1996). Integrated control of Sclerotinia sclerotiorum. Fitopatologia Brasileira, 21(2), 254-260.

Peres, A. P., Nasser, L. C. B., \& Machado, J. C. (2002). Use of semi-seletive media for detection of Sclerotinia sclerotiorumon bean and soybean seeds. Fitopatologia Brasileira, 27(2), 123-127. http://dx.doi.org/10.1590/S0100-41582002000200001

Saidon, G., Huang, H. C., Kozub, G. C., Mundel, H. H., \& Kemp, G. A. (1993). Incide of white mold and yield of upright bean grown in different planting patterns. Journal of Phytopathology, 137(2), 118-124. http://dx.doi.org/10.1111/j.1439-0434.1993.tb01331.x

Stone, L. F., \& Moreira, J. A. A. (2001). Resposta do feijoeiro ao nitrogênio em cobertura, sob diferentes lâminas de irrigação e preparo do solo. Pesquisa Agropecuária Brasileira, 36(3), 473-481. http://dx.doi.org/10.1590/S0100-204X2001000300011

Teixeira, I. R., Andrade, M. J. B., Carvalho, J. G., Morais, A. R., \& CORRÊA, J. B. D. (2000). Resposta do feijoeiro (Phaseolus vulgaris L. cv. Pérola) a diferentes densidades de semeadura e doses de nitrogênio. Ciência e Agrotecnologia, 24(2), 399-408.

Teixeira, I. R., Borém, A., Araújo, G. A. A., \& Fontes, R. L. F. (2004). Manganese and zinc leaf application on common bean grown on a "Cerrado" soil. Scientia Agricola, 61(1), 77-81. http://dx.doi.org/10.1590/S0103-90162004000100013

Tu, J. C. (1997). An integred control of white mold (Sclerotinia sclerotiorum) of beans, with emphasis on recent aduanes in biological control. Botanical Bulletin of Academia Sinica - Phytopathology, 38(2), 73-76.

Valério, C. R., Andrade, M. J. B., \& Ferreira, D. F. (1999). Comportamento das cultivaes de feijão Aporé, Carioca e Pérola em diferentes populações de plantas e espaçamentos entre linhas. Ciência e Agrotecnologia, 23(3), 515-528.

Vieira, R. F., Paula Júnior, T. J., Peres, A. P., \& Machado, J. C. (2001). Fungicidas aplicados via água de irrigação no controle de mofo-branco no feijoeiro e incidência de patógeno na semente. Fitopatologia Brasileira, Brasilia, 26(4), 770-773. http://dx.doi.org/10.1590/S0100-41582001000400015

\section{Copyrights}

Copyright for this article is retained by the author(s), with first publication rights granted to the journal.

This is an open-access article distributed under the terms and conditions of the Creative Commons Attribution license (http://creativecommons.org/licenses/by/3.0/). 